\title{
Muhammad abu Zahra's Muslim Theology of Religions
}

\author{
Mohammed Gamal Abdelnour
}

'His publishers call him Imam, ranking him with the great figures of Islamic scholarship of the past, such as Abu Haneefah, Malik, Al-Shafie and Ibn Taimiyah. Indeed, he has a great affinity with all these, as we will presently explain. If we consider this title on the basis of its linguistic meaning, which is a leader who shows the way, then he certainly was an Imam. And if we take it to mean a scholar of broad and varied knowledge, then he was certainly an Imam.'

Excerpt from an article in Arab News ${ }^{1}$

Muhammad abu Zahra was born on March 29, 1898, in the Nile Delta of Egypt. Following a traditional kuttāb education, ${ }^{2}$ 'he completed his secondary education at al-Ahmadi mosque in Tanta. In 1916, he entered the School of Shari'ah at al-Azhar in Cairo where he graduated in 1925. From 1932 to 1945, he held an appointment at the college of Usul al-Din, first as a teacher of rhetoric, then

\footnotetext{
1 See: http://www.arabnews.com/node/216148.

$2 K u t t a \bar{b}$ : the term goes back at least to the 10th century. It is an Arabic word meaning 'elementary schools'. Though it was primarily used for teaching children in reading, writing, grammar and Islamic studies such as qirā'āt (Qur'anic styles of recitation), other practical and theoretical subjects were also often taught. Until the 20th century, katātīb were the only means of mass education in much of the Islamic world. See: M Arsimov and C E Bosworth, The Age of Achievement, vol. 4 (Delhi: Banarsidass, 1999), pp. 4-33.
} 
as a teacher of the history of religions, denominations, and sects. ${ }^{3}$ At al-Azhar today, abu Zahra is looked at as a polymath who has written over a dozen books on different areas, ranging from international relations in Islam to Islamic legal theories. ${ }^{4}$ Of particular relevance to the Muslim Theology of Religions, he wrote two significant books:

Lectures in Comparative Religion, delivered in 1940 and published in 1965, and Lectures on Christianity, which were held and appeared in 1942. Abu Zahra's audience for his two books on Christianity and on ancient religions is clearly made up of students from al-Azhar. Therefore, his two books reflect a pattern of subconscious mimetic appropriation. ${ }^{5}$

In the areas of Islamic Theology as well as Islamic Law, abu Zahra's views are of capital importance to the modern study of Islam. This importance owes a lot to him being a 'critical insider' in the full sense of the two words. Thanks to an insider criticality, his views travelled far and wide across the Muslim world. In 2001, a British non-profit educational foundation was established and named after him (Abu Zahra Foundation), ${ }^{6}$ aiming to revive this sense of criticality in the minds of Muslims living in the West. Abu Zahra died in 1974.

Abu Zahra's name is closely linked to the critique of the traditional theory of abrogation (naskh). ${ }^{7}$ Although the theory of naskh has been central to the entire genre of Islamic studies, over the past century the theory has largely been critiqued. While abu Zahra's position on naskh has been examined extensively, the impact of such a position on his Muslim Theology of Religions has not been investigated yet, i.e. the salvation question. ${ }^{8}$ This essay investigates two aspects of abu Zahra's Theology of Religions: epistemology and soteriology. To clarify,

3 J Waardenburg, Muslim Perceptions of Other Religions: A Historical Survey (Oxford: Oxford University Press, 1999), p. 244.

$4 \mathrm{~J}$ Brown, Misquoting Muhammad: The Challenges and Choices of Interpreting the Prophet's Legacy (London: Oneworld Publications, 2014), p. 156.

5 Waardenburg, Muslim Perceptions, p. 244.

6 See: http://www.abuzahra.org/about-us/.

7 Naskh is 'making a revealed text supersede another. The grounds on which abrogation can be made are many; one of which is the chronologically later provenance of the repealing text (reflecting a change of mind or position adopted in the earlier text); another reason for abrogation is when one text itself commands the abandonment of a matter specified in another text'. See: W Hallaq, An Introduction to Islamic Law (Cambridge, Cambridge University Press, 2009), p. 171.

8 It is worth mentioning that abu Zahra did not solely reject naskh in order to provide the scriptural and theological ground for the potential salvation of non-Muslims, but rather his critique of naskh serves other purposes as well. Indeed, this shows the centrality of naskh in the Islamic traditions. 
the epistemological question is concerned with evaluating the phenomenon of religions in terms of their efficacy of leading a valid path to salvation, whilst the soteriological question asks whether religions other than one's own have a chance of salvation in the Hereafter regardless of being salvifically effective or not. The chapter does not engage with naskh in the Sunnah (prophet Muhammad's legacy); it only engages with it vis-a-vis the Qur'an. It is, too, beyond the scope of this study to examine the theory of naskh in itself, but only to provide a context to abu Zahra’s Muslim Theology of Religions.

\section{The ‘epistemology' question (Naskh Theory)}

While naskh is accentuated by the majority of classical Muslim ulema and largely seen as a matter of 'doctrine', modern Islamicist scholars tend to question this outlook, seeing naskh primarily as an 'exegetical device' rather than a matter of 'doctrine'. A concrete example of this modern phenomenon is John Burton, who maintains that:

The theory of naskh was an invention of Figh scholars and that a careful examination of the Qur' an itself produces no evidence that naskh of the sort of Fiqh scholars had in mind is envisioned in or exemplified by the Qur'an. The theory of naskh was developed as an exegetical device for dealing with apparent contradictions within the corpus of sacred texts; it allowed chronology to intervene as a means of eliminating real contradictions. ${ }^{9}$

Ahmad Hassan traces the theory back to the end of the first century of the Hijrah (the Prophet Muhammad's migration from Mecca 622 CE to Medina). He states: 'the idea of abrogation in the Qur' anic verses must have appeared towards the end of the first century of the Hijrah, because it existed in the early schools of law.' ${ }^{10}$ However, it actually originates from the time of the companions of Muhammad. ${ }^{11}$ Upon hearing the central Qur'anic verse on naskh; verse number 106, Sura 2, which reads:

9 B Weiss, 'The Sources of Islamic Law: Islamic Theories of Abrogation by John Burton', in The American Oriental Society 113.2 (1993), p. 304.

10 A Hassan, The Theory of Naskh, vol. 4 (Islamabad: International Islamic University, 1965), p. 184.

11 F Esack, Qur'an Liberation \& Pluralism: An Islamic Perspective of Interreligious

Solidarity Against Oppression (Oxford: Oxford University Press, 1997), p. 58. 


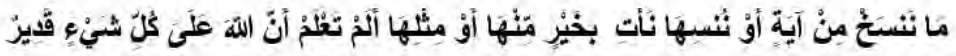

and translates to: 'Any revelation We cause to be superseded or forgotten, We replace with something better or similar. Do you (Prophet) not know that God has power over everything,' ${ }^{12}$ the companion Umar said: 'Ubbay is the best one to recite the Qur'an among us and Ali is our best judge, and we ignore what Ubbay says in that he does not leave anything he hears from the Messenger of God though God High Exalted has said: (for whatever order We repeal or allow to be forgotten... etc). ${ }^{13}$ What can be inferred from Umar's statement is that naskh has been discussed among the companions of the Prophet, and since Ubbay was against it, it can also be inferred that the theory was not unanimously accepted.

One question that needs to be asked, however, is whether this hadith can stand as a proof for the rejectionists of naskh? It is highly unlikely that it can be used as such, since Ubbay was not against the theory per se, but apparently was against relinquishing something he knows for certain, i.e. having heard it himself directly from the Prophet, to something that has been transmitted to him through a third person, which may be less authentic. Therefore, for Ubbay, it is not a question of questioning naskh itself, but one of authentication. Yet Ubbay's position is still of relevance to abu Zahra in the sense that Ubbay must have interpreted this Qur'anic verse differently. That is to say, Ubbay does not seem to think that naskh can be deduced from such a verse and does not also seem to think it a matter of doctrine.

By way of investigating the central Qur'anic verse that seems to be highly endorsing naskh, a tripartite typology is offered. ${ }^{14}$ This typology comprises the following elements: sibāq (prior-text), lihāq (post-text), and siyāq (context). Sibāq is what comes immediately before the examined text in terms of the Qur'anic ordering of verses; lih $\bar{a} q$ is what comes after it; and siy $\bar{a} q$ is basically the context wherein the prior-text, text and post-text meet. Indeed, any interpretation of a

12 M A S Abdel Haleem, The Qur'an: A new Translation (Oxford: Oxford University Press, 2010), p. 13.

13 Al-Bukhari, Mokhtasar Sahih al-Bukhari, transl. Dina Zidan and Ahmad Zidan (Cairo: Islamic INC. Publishing \& Distribution, 1999), p. 928.

14 Although this tripartite typology is not literally developed by the classical Muslim scholars, implications of it can be found in the early tafsir writings such as Tafsir al-Tabari (d. 310/923). See: Abdel-Hakeem al-Qasim, Dilalat al-siyaq al-Qur'ani wa atharutha $\mathrm{fi}$ al-tafsir, vol. 1 (Riyadh: Dar al-Tadmuriyyah, 2012). 
Qur' anic text/verse that does not consider the prior-text as well as the post-text is believed not to adequately grasp the text. ${ }^{15}$ In the pages that follow, this tripartite typology is applied to the Qur' anic verse at hand.

Discussing the verse quoted above, abu Zahra argues that most of the Qur' anic exegetes interpret the verse out of context. This mis-contextualisation occurs in taking the word iَيَّة in this verse to mean a literal Qur'anic verse (a piece of Qur'anic revelation), while, according to the Arabic lexical dictionaries, ${ }^{16}$ the word is a homonym that has various connotations. ${ }^{17}$ With that being said, interpreting the word آيَة here as a Qur'anic verse is not necessarily the only feasible option. Furthermore, such an interpretation is not espoused by neither the prior-text, nor the post-text, and therefore is not conductive toward delivering the message of the text adequately.

Two types of prior-texts can be introduced here. ${ }^{18}$ First, 'textual prior-text'; second: 'historical prior-text'. The 'textual prior-text', in this context, is the verse that immediately precedes the examined Qur' anic verse, as opposed to the 'historical prior-text', which refers to an incidence/occasion that has happened in correspondence with the revelation. Regarding the 'textual prior-text', the Qur'anic verse that precedes ours, reads:

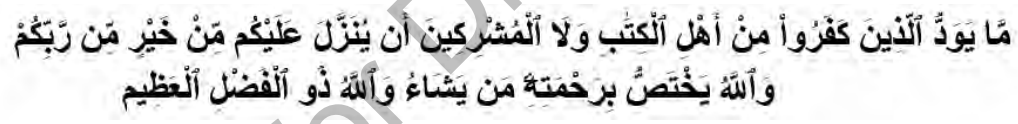

which translates as: "neither those People of the Book who disbelieve nor the idolaters would like anything good to be sent down to you from your Lord, but God chooses for His grace whoever He will: His bounty has no limits. ${ }^{, 19}$ This verse has nothing to do with the theory of abrogation in the traditional sense of

15 M Abu Zahra, Usul al-Fiqh (Cairo: Dar al-Fikr al-Arabi, 1958), p. 184-197.

16 See: J M Cowan, Arabic-English Dictionary (New York: Spoken Languages Services, 1976), p. 36.

17 Although the primary meaning of the word a $y$ ah is divine sign/sign of God, the word holds nine other possible meanings: 1) proof/evidence; 2) miracle/portent; 3) exemplar/ symbol; 4) revelation/message; 5) teachings/instructions; 6) Qur'anic verses; 7) lesson; 8) glory/wonder; 9) spell. See: M Badawi and M A S Abdel Haleem, Arabic-English Dictionary of Qur'anic Usage (Leiden \& Boston: Brill, 2008), pp. 68-96.

18 See: M A S Abdel Haleem, 'The Role of Context in Interpreting and Translating the Qur'an', in Journal of Qur'anic Studies 20 (2018), pp. 47-66.

19 Abdel Haleem, The Qur'an, p. 13. 
the term. Therefore, interpreting the next verse in terms of abrogating certain Qur' anic verses is tantamount to taking the verse out of its context. ${ }^{20}$

What about the historical prior-text? The verse above corresponds with an occasion that happened in the time of Prophet Muhammad; an occasion that verse 153, Sura 4, talks about, which reads:

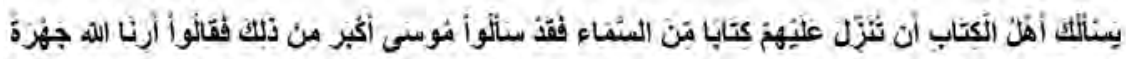

translated as: 'The People of the Book demand that you (Prophet) make a book physically come down to them from heaven, but they demanded even more than that of Moses when they said, (Show us God face to face). ${ }^{21}$ Linking the two verses together, the Qur'an tells the Prophet in Sura 2 that the unbelievers of Mecca were demanding a physical miracle, rather than an incorporeal one, i.e. the Qur'an. That is to say that the verses of Sura 2 were highly likely revealed as a response to the Meccan's demand; a response that lays down the foundations of Allah's law of miracles, stating that: 'any physical miracle We cause to be superseded or forgotten, We replace with a better or similar [i.e. non-physical] miracle' (the Qur' an). ${ }^{22}$ Based on the above, interpreting the word آيَة here as a Qur'anic verse is highly remote, for the word $\bar{a} y a h$ is not necessarily a Qur'anic verse but highly likely a physical miracle, if we consider the context. In fact, this is the capacity in which the Qur'an, more often than not, uses the term $\bar{a} y a h .^{23}$ As a corollary to this, neither the 'textual prior-text' or the 'historical prior-text' endorse the naskh interpretation, unless taken out of the 'prior-text' context, whether historical or textual.

The post-text, in this case, is verse number 108, which reads:

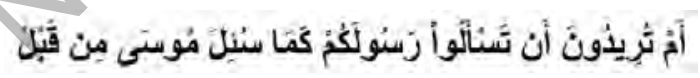

translated as: 'Do you wish to demand of your messenger something similar to what was demanded of Moses?'24 The question that then arises is: what was demanded of Moses other than physical miracles? The Qur'an talks about the

20 Abu Zahra, Usul, pp. 184-197.

21 Abdel Haleem, The Qur'an, p. 64.

22 Abdel Haleem, The Qur'an, p. 13.

23 See for instance: verse number 50, Sura 2, discussing the physical miracles of Jesus Christ.

24 Abdel Haleem, The Qur'an, p. 13. 
Jews asking Moses all the time for physical miracles. ${ }^{25}$ Historically speaking, this has also been demanded of Muhammad by the unbelievers of Quraysh. Why should an exegete then ignore the textual and historical prior-text and the textual and historical post-text for a literal reading? Indeed, ignoring the prior-text and the post-text, argues abu Zahra, seems to have diverted the majority of Qur'anic exegetes from a logical interpretation based on the context of the verse. ${ }^{26}$

Abu Zahra constantly reminds his readers that a Qur' an exegete is not to resort to the theory of naskh as long as there is another way with which the apparently contradictory Qur'anic verses can be reconciled. And since all verses as such can be reconciled without resorting to naskh, abu Zahra rejects the practice entirely, stating that the reliance on naskh has caused many controversies between Qur'anic exegetes. In this respect, Kamali writes:

The conventional theory of naskh has not been free of distortion and forced logic, yet the scholastic works of the madhâhib took for granted the conceptual validity and occurrence of abrogation in the Qur'an and Sunnah. The inherent tension that is visited here has perhaps been manifested in the ulema's disagreement over the actual incidents of naskh in the Qur'an, and the distinction that is drawn between naskh, and specification of the general (takhsīs al- 'âmm). Some of the instances of naskh were accordingly seen to be amounting to no more than takhsis. The scope of disagreement over the occurrence of naskh was initially very wide and claims of several hundred instances of naskh in the Qur'an were gradually scrutinized and reduced by Jalāl al-Dīn al-Suyūtī, for example to about 30 cases, and then to only five by Shāh Walī Allāh Dihlawī. One of the early fourth century commentators of the Qur'an, Abū Muslim al-Isfāhnī, even claimed that abrogation had no place in the Qur'an whatsoever, stating that all the alleged cases of naskh were in effect instances of $t a k h s \bar{i} s .$. the basic tension between the classical theory of naskh and the timeless validity of the Qur'an prompted Imām al-Shāfi'ì into advancing the view that naskh was a form of explanation (bayān), rather than annulment, of one ruling by another. ${ }^{27}$

25 The al-Baqarah Sura reflects this. 26 M Abu Zahra, Usul, pp. 184-197.

27 M H Kamuli, 'Methodological Issues in Islamic Jurisprudence', in Arab Law Quarterly 11.1 (1996), pp. 13-14. 


\section{How Does abu Zahra's Take on Naskh Influence His Muslim Theology of Religions?}

Abu Zahra's lack of subscription to the theory of naskh meant, inter alia, that he had to offer different readings of certain other Qur' anic verses, amongst which are those verses that talk about the fate of non-Islamic religions. In his, Zahrat al-Tafasir (literally translates as: The Flowers of Exegeses), abu Zahra deals elaborately with the central Qur' anic verse that discusses non-Islamic religions. This is verse number 62 in Sura 2, arguably the most pluralistic of Qur' anic verses. The verse reads:

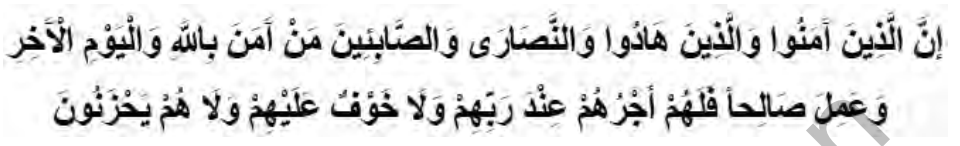

and translates as: 'The (Muslim) believers, the Jews, the Christians, and the Sabians - all those who believe in God and the Last Day and doing good - will have their rewards with their Lord. No fear for them, nor will they grieve. ${ }^{28}$ Looking into the Qur'an commentaries shows that the vast majority of Qur'an exegetes explicate this verse in one of two ways: 1) subscribing to abrogation by stating that this verse is abrogated by verse number 85 , Sura 3 , which reads: 'Whoever seeks a way other than Islam, it will never be accepted from them, and in the Hereafter, they will be among the losers; ${ }^{29}$ or 2) specifying the generality of the verse, saying, for instance, that the acknowledged Christians, Jews, etc. here are only those who adhered to these religions before the advent of Prophet Muhammed, but when Muhammad came, they followed his message. ${ }^{30}$

Under the title, 'People are all Alike in the Sight of God if they Believe', abu Zahra explicates the verse at hand, looking at it as a statement from God to all humans, stating that 'belief' is accepted from all faith-groups and religious denominations as long as they believe in God, the Day of Judgement and perform good deeds. ${ }^{31}$ This is the prime vehicle to salvation, abu Zahra says. Immersing himself in the discussion on a deeper level, abu Zahra examines these religions one by one. Starting with Islam, abu Zahra states that whoever follows Prophet Muhammad and aides his belief with the performance of good deeds that please

28 Abdel Haleem, The Qur'an, p. 9.

29 Khattab, The Clear Qur'an: A Thematic English Translation (Canada: Siraj Publications, 2016), p. 95.

30 See full discussion on the exegeses of this verse in: J D McAuliffe, Qur'anic Christians: An Analysis of Classical and Modern Exegesis (Cambridge: Cambridge University Press, 1991), pp. 93-128.

31 M Abu Zahra, Zahrat al-Tafasir (Cairo, Dar al-Fikr al-Arabi, 1987), p. 254. 
God and benefits His creatures, is to appear under the category of those who need have no fear, and who will be spared from grief in this life and in the Hereafter. ${ }^{32}$

The same principal applies to non-Islamic religions. If Christians, Jews, Sabians, or any other faith group, believe in 'God, and that He begot no one nor was He begotten', and who believe in all his messengers and in the Hereafter, there will be no fear for them nor will they grieve. ${ }^{33}$ However, abu Zahra offers a more detailed analysis when it comes to the Christians, arguing that there are two major disagreements between Christianity and Islam. The first one is to do with God and the second is to do with Prophet Muhammad. On the disagreement about God, abu Zahra explains: ${ }^{34}$

Some Christians say that the Qur' an itself assures them that there will be no fear for them nor will they grieve; a statement that gives recognition to Christianity as a valid path to salvation on its own merits. We say: the Qur'an gives them that recognition on the condition that they believe in the oneness of God, He begot no one nor was He begotten, and that no one is comparable to Him. Do the Christians of today believe in these principals?! They rather say that God is a third of three, while God in the Qur'an says: Those who say 'God is one in a trinity' have certainly fallen into disbelief. They maintain, from the time of the Nicaean Council until this day, that Jesus Christ is divine, while the Qur' an says: Those who say 'God is the Messiah, son of Mary' have certainly fallen into disbelief. 35

As for the second disagreement, in his discussion of verse number 20, Sura 3, abu Zahra denies the salvation of anyone who denies the prophethood of Prophet Muhammad. By way of reconciling the two discussions, abu Zahra seems to be arguing for the salvation of whoever acknowledges Muhammad as a Prophet even if they remain true to their religious tradition without converting to Islam. Hence abu Zahra, on the one hand, accepts that there is salvation outside of Islam (differing from the Exclusivists who see Islam as the only valid path to salvation), but on the other hand holds that one has to be a monotheist and acknowledge the message of Muhammad in order to gain salvation. Whether or not Christians are trinitarians in the way most Muslims understand trinity is a question to be studied in its

32 Abu Zahra, Zahrat, p. 254.

33 Abu Zahra, Zahrat, p. 254.

34 Unless otherwise stated, the translation is mine.

35 Abu Zahra, Zahrat, p. 256. 
own merits, but of relevance here is that abu Zahra features as a 'Theo-centric theologian', which is a transformative shift in the Muslim Theology of Religions, for all Qur' an exegetes require not just believing in God as well as acknowledging Prophet Muhammad's prophethood, but conversion to Islam. Although abu Zahra is not the first to have such a position on non-Islamic religions, ${ }^{36}$ his position is remarkable in that he solidifies it on the basis of his position on abrogation, which gives some epistemic recognition to non-Islamic religions, making the message of Islam more of a confirmatory nature to the previous monotheistic messages rather than one of abrogatory nature.

Furthermore, the verse which is used by the majority of commentators to abrogate the verse central to this essay, is used by abu Zahra in quite a different manner, that is, for confirming his Theo-centrism. ${ }^{37}$ This is verse number 85 , Sura 3, which reads:

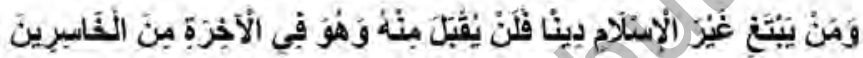

and which translates as: 'Whoever seeks a way other than Islam, it will never be accepted from them, and in the Hereafter, they will be among the losers. ${ }^{38}$ While most of the Qur' an exegetes take the word 'Islam' here to be technical Islam, abu Zahra considers it a linguistic term. That is to say that the word Islam in this verse does not mean the Religion Islam, but islam as a word that implies surrendering to God and submitting to Him alone. To abu Zahra, the term islam can be replaced with 'purity/sincerity' ${ }^{39}$

To conclude, abu Zahra gives epistemic recognition and salvation efficacy to any religion that is of monotheistic nature, believes in all prophets of God and encourages good deeds. These are the three prime requisites for an individual to lead a valid path to salvation. In the pages that follow, the fate of those who do not tread the path to salvation will be examined.

36 The Reformist School of Muhammad Abduh has a quite similar view.

37 'Theo-centrism' is not to be confused with 'pluralism'. Although there is some significant overlap, theo-centrism revolves around God while pluralism revolves, in very generic terms, around the concept of the 'Real'. See: http://www.ips.org.pk/ theocentrism-and-pluralism-are-they-poles-apart/.

38 Khattab, A Thematic English Translation, p. 95.

39 Abu Zahra, Zahrat, p. 1302. 


\section{The 'soteriology' question}

\section{Do non-Islamic religions have a chance of salvation in the Hereafter?}

Whereas the previous discussion was primarily epistemological, what is to come is substantially soteriological. The soteriological question here is: what is the fate of those non-Muslims who fail to meet the three requirements of salvation? More generally, what about those individuals who greatly contribute to the enhancement of people's lives? Would they simply be thrown into perdition as a result of their failure to embrace Islam? While modern Muslim scholars disagree on this question, the traditional position holds that such scholars, scientists and God-conscious people are entitled to a secular reward, e.g. being wealthy, healthy, praised in public, etc., but they are not entitled to a reward in the Hereafter. This is simply because in Islam a good deed will rewarded under two conditions of correct conduct and sincerity: 1) the deed must be conducted in compatibility with God's laws which have been revealed to Prophet Muhammad; 2) the intention has to be worshiping God and getting closer to Him through the performance of a good deed..$^{40}$ Based on these two conditions, such a category of people are entitled only to a secular reward in the Here, but not in the After. This is the traditional view.

The proceedings of a roundtable discussion, published in al-Azhar mosque magazine in 1955, shows that although many modern Muslim scholars were in line with the traditional position, a few were an exception. Abu Zahra participated in the roundtable and discussed this thorny question, concluding that anyone who meets the requirements of salvation in the Here will be saved in the After even if he does not convert to Islam. As for those who fail to meet any of these requisites, abu Zahra makes it 'clear that the deeds of non-Muslims, performed for the sake of humanity, are religiously meritorious in themselves, at least in circumstances in which the non-Muslim is not culpable for not adhering to Islam'. ${ }^{41}$

Accordingly, abu Zahra affirms that God's consciousness is the kernel and cornerstone of salvation. From verse number 115, Sura 3, which reads:

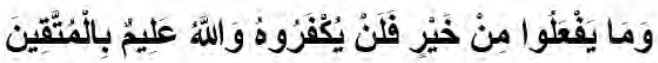

and translates as: 'And they will not be denied (the reward) for whatever good deeds they do: God knows exactly who is conscious of Him,'42 abu Zahra borrows

40 M H Khalil, Between Heaven and Hell: Islam, Salvation, and the Fate of Others (Oxford: Oxford University Press, 2013), p. 46.

41 Khalil, Heaven and Hell, p. 46.

42 Abdel Haleem, The Qur'an, p. 43. 
the foundation of his theocentric position and makes a more obvious stance. ${ }^{43}$ It should be noted that this is abu Zahra's position on a verse that is interpreted by the majority of Muslim scholars to be entitling good non-Muslims to secular rewards only.

\section{Conclusion}

In this investigation, two aims were sought after. First, to introduce abu Zahra's position on the theory of naskh to the English reader, providing a hermeneutical tool that, more adequately, situates his position in the field of textual hermeneutics; a tool that I identify as 'the tripartite typology', and which comprises the three notions of sibāq (prior-text), lihāq (post-text), and siy $\bar{a} q$ (context). The second and prime aim of this essay was to show how abu Zahra's position on naskh influences his Muslim Theology of Religions epistemologically and soteriologically.

The most obvious finding to emerge from this paper is that abu Zahra can be possibly classified as a theocentric theologian whose theology of religions starts from God and revolves around Him rather than being centred on the Prophet. Abu Zahra's position is unique in the sense that although he is not an exclusivist in terms of salvation, he also is not a pluralist. That is to say that he is against loosening the religious differences and blurring the boundaries between the different faiths. The emphasis he places on the question of the Trinity makes this crystal clear.

One of the more significant findings to emerge from this chapter is that an exegete is not to explicate a Qur'anic verse in a vacuum. That is to say that the hermeneutical tool applied in the course of reading abu Zahra shows how considering the sibāq, lihāq, and siyāq can definitely play a significant role in grasping the Qur'anic message.

\section{Bibliography \\ Books}

Abdel Haleem, M A S, The Qur'an: A new Translation (Oxford: Oxford World's Classics, 2010).

Abu Zahra, M, Usul al-Fiqh (Cairo: Dar al-Fikr al-Arabi, 1958).

Abu Zahra, M, Zahrat al-Tafasir (Cairo: Dar al-Fikr al-Arabi, 1987).

43 Abu Zahra, Zahrat, p. 1371. 
Al-Bukhari, Mokhtasar Sahih al-Bukhari: Text and Translation, transl. Dina Zidan and Ahmad Zidan (Cairo: Islamic INC. Publishing \& Distribution, 1999).

Al-Qasim, A, Dilalat al-siyaq al-Qur'ani wa atharutha fi al-tafsir, vol. 1 (Riyadh: Dar al-Tadmuriyyah, 2012).

Arkoun, M, Rethinking Islam, Common Questions and Uncommon Answers, ed. and transl. Robert Lee (Colorado: Westview Press, 1994).

Arsimov, M S, and Bosworth, C E, The Age of Achievement, vol. 4 (Delhi: Banarsidass, 1999).

Badawi, E, and Abdel Haleem, M, Arabic-English Dictionary of Qur'anic Usage (Leiden \& Boston: Brill, 2008).

Brown, J, Misquoting Muhammad: The Challenges and Choices of Interpreting the Prophet's Legacy (London: Oneworld Publications, 2014).

Cowan, J M, Arabic-English Dictionary (New York: Spoken Languages Services, 1976).

Esack, F, Qur'an Liberation \& Pluralism: An Islamic Perspective of Interreligious Solidarity Against Oppression (Oxford: Oneworld Publications, 1997).

Goldziher, I, Introduction to Islamic Theology and Law, transl. Andras and Ruth Hamori (Princeton: Princeton University Press, 1981).

Hallaq, W, An Introduction to Islamic Law (Cambridge: Cambridge University Press, 2009).

Hassan, A, The Theory of Naskh, vol. 4 (Islamabad: International Islamic University, 1965).

Jackson, S, On the Boundaries of Theological Tolerance in Islam (Oxford: Oxford University Press, 2002).

Kärkkäinen, V, An Introduction to the Theology of Religions: Biblical, Historical and Contemporary Perspectives (Downers Grove: Intervarsity Press, 2003).

Khalil, M H, Between Heaven and Hell: Islam, Salvation, and the Fate of Others (Oxford: Oxford University Press, 2013).

Khattab, M, The Clear Qur'an: A Thematic English Translation (Canada: Siraj Publications, 2016).

Lamptey, J, Towards a Muslima Theology of Religious Pluralism: The Qur'an, Feminist Theology and Religious Diversity (Georgetown: $\mathrm{PhD}$ thesis at the University of Georgetown, 2011).

McAuliffe, J D, Qur'anic Christians: An Analysis of Classical and Modern Exegesis (Cambridge: Cambridge University Press, 1991). 
Waardenburg, J, Muslim Perceptions of Other Religions: A Historical Survey (Oxford: Oxford University Press, 1999).

\section{Articles}

Abdel Haleem, M A S, 'The Role of Context in Interpreting and Translating the Qur'an', in Journal of Qur'anic Studies 20 (Edinburgh: Edinburgh University Press, 2018), pp. 44-66.

Barzegar, A, 'The Persistence of Heresy: Paul of Tarsus, ibn Saba, and Historical Narrative in Sunni Identity Formation', in Cultural Memory and Islam 58.2/3 (2011), pp. 202-231.

Kamali, M H, 'Methodological Issues in Islamic Jurisprudence', in Arab Law Quarterly 11.1 (1996), pp. 3-33.

Weiss, B, 'The Sources of Islamic Law: Islamic Theories of Abrogation by John Burton’, in Journal of the American Oriental Society 113.2 (1993), pp. 304-306.

\section{Online Sources}

Abu Zahra, M, Abu Zahra Foundation website, available at: http://www. abuzahra.org/about-us/.

Morados, M, ‘Theocentrism and Pluralism: Are they Poles Apart?’, available at: http://www.ips.org.pk/theocentrism-and-pluralism-are-they-poles-apart/.

Salahi, A, 'Scholar of renown: Muhammad Abu Zahrah', in Arab News, available at: http://www.arabnews.com/node/216148. 